\title{
Relação Entre A Qualidade Microbiológica de Linguiça do Tipo Frescal e Sua Respectiva Temperatura de Armazenamento
}

Samira Obeid Georges (II), Larissa Gomes Bernardo (II), Liana Jayme Borges (II), Maria Cláudia Dantas Porfírio Borges André (III)

(II) FANUT/ UFG - Faculdade de Nutrição da Universidade Federal de Goiás (Rua 227 Qd. 68 S/N-St.Leste Universitário-Goiânia(GO)-Brasil-CEP:74.605-080), (III) IPTSP/ UFG - Instituto de Patologia Tropical e Saúde (Rua 235 S/N esquina com a 1를 Avenida-Setor Leste UniversitárioGoiânia(GO))

\section{Resumo}

Introdução. A linguiça do tipo frescal é evidenciada no comércio brasileiro por ser bem aceita e comercializada. Devem permanecer armazenadas sob refrigeração até a compra, visto que a temperatura é um fator capaz de contribuir para o desenvolvimento de micro-organismos capazes de ocasionar toxinfecções alimentares. Material e Métodos. Foram coletadas em açougues do Município de Aparecida de Goiânia - Goiás, 87 amostras de linguiça frescal nos meses de julho a agosto de 2013. Nas coletas, aferiu-se a temperatura das linguiças e a do balcão de sua armazenagem. Posteriormente, as amostras foram submetidas à análise microbiológica de acordo com a RDC no 12/2001. Resultados e discussão: Não foram isoladas Salmonella spp. nem Clostrídio Sulfito Redutor nas linguiças. No entanto, foi possível realizar a contagem de Coliformes termotolerantes e Estafilococos coagulase positiva. De acordo com as contagens realizadas, as amostras foram enquadradas em sete classes. Tais classes enquadraram os valores de contaminação que variaram de 0 a 13.240 UFC das amostras analisadas. Por meio de correlação linear simples, comparou-se a relação das classes com a temperatura das linguiças (de $-3,7$ a $15,3^{\circ} \mathrm{C}$ entre as amostras) e do balcão (de -6 a $12^{\circ} \mathrm{C}$ entre os açougues). Observou-se que a temperatura do balcão influenciava pouco na temperatura das linguiças, permitindo analisar que fatores externos influenciavam na temperatura das 
mesmas. Além disso, linguiças com temperaturas mais elevadas estavam relacionadas às classes maiores, representantes de valores de contaminação mais altos, ou seja, maior contagem de coliformes e estafilococos esteve relacionado com variação de temperatura das linguiças (relação direta). No que tange a Salmonella spp., embora o presente estudo não a tenha isolado, a maioria das pesquisas relatam seu isolamento, mesmo que em baixas contagens, sendo seu desenvolvimento facilitado pela variação de temperatura. Quanto ao Clostrídio, ressalta-se que sua ausência na presente pesquisa pode ser justificada pelo mesmo se tratar de uma bactéria termófila, sendo sua presença e multiplicação dificultada pelas temperaturas de refrigeração. Conclusão. A temperatura é um fator capaz de contribuir para o desenvolvimento de bactérias patogênicas no alimento. Ressalta-se, por fim, a importância de armazenar as linguiças sob temperatura de refrigeração $\left(<4^{\circ} \mathrm{C}\right)$.

Palavras-Chave: Linguiça frescal, Microbiologia de alimentos, Temperatura Agência de Fomento: 